\title{
NOG EENS: VERZUIMD ST. EUSTATIUS \\ DOOR
}

\section{MR. M. VAN DIJK}

Door een samenloop van omstandigheden ben ik tot heden, als ik het zoo noemen mag, een antwoord schuldig gebleven aan Prof. Dr. L. Knappert, die in een zeer belangrijke voordracht, gehouden in de maandvergadering van de Maatschappij der Nederlandsche Letterkunde te Leiden den 3den Mei 1929, opgenomen in dit tijdschrift (Juli/Augustus 1929, elfde jaargang, no. 3/4) en getiteld "Verzuimd St. Eustatius", naar aanleiding van den ten

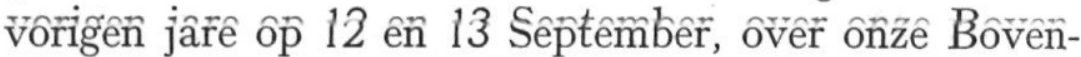
windsche eilanden gewoed hebbenden orkaan, eenige opmerkingen maakt (opgenomen op blz. 171 tot en met 174), waartegen naar mijne meening het een en ander valt aan te voeren. Waar Prof. Knappert aan het einde zijner voordracht zelf zegt:

\footnotetext{
„De schrijver dezer bladzijden, die nimmer op het eiland was, is er zich wel van bewust, dat hij fouten heeft kunnen maken. Van de hoofdzaak mogen die de aandacht niet afleiden. Indien het hem maar gelukt zij, belangstelling te wekken of te verlevendigen voor dit kleine verzuimde stukje van het Nederlandsche Rijk!"

doe ik dit in het vertrouwen, dat het onderstaande daartoe moge bijdragen.

Echter betreffen de opmerkingen van Prof. Knappert min of meer mijn beleid als waarnemend Gouverneur van Curaçao te dien opzichte, zoodat mijn tegenbetoog allicht het karakter zou krijgen, althans den schijn hebben van een oratio pro domo.

Teneinde dit te voorkomen, moge ik volstaan met het weergeven van eenige openbaar gemaakte stukken betreffende deze aangelegenheid.
} 
Allereerst dan een stuk in de Amigoe di Curaçao, bijblad, van 11 Mei 1929, no. 2366, naar aanleiding van een ingezonden stuk in dat blad van 4 Mei daaraanvoorafgaande, waarin overeenkomstige opmerkingen gemaakt werden als door Prof. Knappert in zijn voordracht, onderteekend door „Tiller of the Soil”, luidende:

\section{ST. EUSTATIUS EN DE STORM}

„Naar aanleiding van het ingezonden stukje met betrekking tot St. Eustatius in ons blad van de vorige week, waarin een blaam geworpen wordt op hetgeen de toenmalige waarnemend-Gouverneur, de Gezaghebber der Bovenwindsche eilanden en de plaatsvervangend Gezaghebber van het eiland zelf in verband met den storm van 12 op 13 September 1928 hebben verricht, vernemen wij nog uit goede bron, dat de voorstelling van zaken geheel anders is, en de genoemde drie mannen zeker geen blaam verdiend hebben voor al hetgeen zij, ieder naar zijn vermogen, gedaan hebben, al zullen hunne bemoeiingen evenmin volmaakt zijn geweest als eenig ander menschelijk werk.

Zooals reeds eenige malen in ons blad tot uiting gekomen is, bestaat er bij een minderheid op Statius animositeit tegen den persoon van den plv. Gezaghebber van dat eiland, welke openlijk naar buiten trad bij de gebeurtenissen tengevolge van den storm.

Dat daarbij van beide zijden minder aangename dingen zullen zijn geuit spreekt van zelf, maar uit het later op last van den wnd. Gouverneur ingesteld onderzoek naar aanleiding van een bij hem daarover tegen den plv. Gezaghebber ingediende klacht bleek dat deze naar zijn beste weten en inzicht gehandeld had en alles gedaan had wat hij menschelijker wijze gesproken op dat oogenblik kon doen. Dat de tot uiting gekomen animositeit daarbij niet weinig hinderlijk gewerkt had, behoeft geen betoog.

Inderdaad verbleef de wnd. Gouverneur op St. Martin, het hoofdeiland en standplaats van den Gezaghebber der Bovenwindsche eilanden, drie dagen. Hiervan was een Zondag; de beide overige dagen werden besteed aan besprekingen met betrekking tot den storm voor alle drie de eilanden, en bezichtiging van de weinige schade op dat eiland zelf, welke met medewerking der bevolking grootendeels weer was hersteld. Op Saba werd twee dagen verbleven, waarvan één dag tot bezichtiging van de aangerichte schade, die op dat eiland in geldswaarde berekend het grootste is geweest, doch welke met volle medewerking der bevolking reeds grootendeels was hersteld; de tweede dag werd besteed aan de noodzakelijke bezichtiging van terreinen diep het eiland in, en had dus niets met den storm uitstaande. Op Statius werd een dag verbleven; hoewel toen niet terzake dienende verklaarde de wnd. Gouverneur zich, desgevraagd, bereid nogmaals en thans persoonlijk en in bijzijn van den Gezaghebber en diens plaatsvervanger de klagers tegen laatstgenoemde aan te hooren. Nadat de aangelegenheid rustig besproken was, moesten zij tenslotte zelf erkennen, dat de geheele klacht hierop neer kwam, dat naar hun inzicht de persoon van den plv. Gezaghebber voor dat ambt niet geschikt was en zij liever een ander wenschten. Het overige gedeelte van den dag werd besteed aan bezichtiging der stormschade, waarvan nog zoo goed als niets was hersteld en opgeruimd; ingewijde en objectieve beoordeelaars, verklaarden den wnd. Gou- 
verneur, dat dit eensdeels te wijten was aan het groote gebrek aan werkkrachten ter plaatse, doch grootendeels aan de weinige medewerking der bevolking. $\mathrm{Zij}$, die hadden medegewerkt, waren reeds zoo goed mogelijk geholpen en dan ook reeds in het bezit van een nieuw huisje.

Terug op Curaçao besprak de wnd. Gouverneur met het stormcomité de wijze van verdeeling der gelden; algemeen achtte men het juist dit den Gezaghebber over te laten, zich daarbij niet ontveinzend, dat, hoe men dat ook zou regelen en in wiens handen men dat ook zou leggen, er altijd ontevredenen zouden zijn. Uit het ingezonden stuk blijkt inderdaad, dat dit ook nu weer het geval is. Maar een ieder, die den Gezaghebber der Bovenwindsche eilanden kent, en in de gelegenheid geweest is, om waar te nemen, hoe hij nu reeds lange jaren zijn beste krachten aan die eilanden wijdt en dat in het bijzonder weer gedaan heeft gedurende en na den orkaan van September 1928, zal vertrouwen stellen in zijn beleid en rechtvaardigheid ook ten opzichte van de verdeeling van de steungelden, hetzij in baar geld, hetzij in natura. Met een gerust geweten kan dit dien man, die op alle drie eilanden algemeen geacht en geëerd wordt, toevertrouwd worden; ongetwijfeld zullen ook zijn bemoeiingen niet volmaakt zijn, en zal ook hij daarbij mogelijk vergissingen begaan. Maar een blaam, als in het ingezonden stuk op hem geworpen, verdient hij allerminst."

Vervolgens het antwoord van Gouverneur Fruytier op de door den Kolonialen Raad gevraagde inlichtingen betreffende het verzoekschrift van de Heeren van Putten c.s. den avond van dienzelfden 11 den Mei 1929 in de openbare vergadering van genoemd College bekend gemaakt en opgenomen in de officieel gedrukte stukken daarvan (zittingsjaar 1928-1929, notulen, no. 24), luidende:

„De Voorzitter doet thans mededeeling van de volgende ingekomen stukken:

$1^{\circ}$. enz

$2^{\circ}$. een gouvernements-depêche dd. 26 April 1929 no. 661 , luidende: „In antwoord op het schrijven dd. 22 Februari 1929, no. 10 van den Kolonialen Raad, heb ik de eer Uw College het navolgende mede te deelen. Na ontvangst van het verzoekschrift dd. 1 October 1928 van de Heeren J. S. van Putten en J. G. Lespier, waarvan een afschrift is opgenomen in de notulen van Uwe vergadering van den 22sten Januari dj, no. 17, werd er door den Gezaghebber van de Bovenwindsche Eilanden, op dezerzijdsch verzoek, ter plaatse een onderzoek ingesteld naar aanleiding van de tegen den plaatsvervangenden Gezaghebber op St. Eustatius geuite klachten. Uit dit onderzoek bleek niet, dat deze in zijne daden tegenover de Statiaansche bevolking gedurende en na den orkaan van 12/13 September 1928 zou zijn tekort geschoten. Zooals uit de Uwen Raad hierbij in afschrift aangeboden notulen van de vergadering van den Raad van Politie op bedoeld eiland van 7 October 1928 blijkt, hebben de Landraden op een desbetreffend verzoek van den Gezaghebber van de Bovenwindsche eilanden, eenstemmig verklaard, dat door den plaatsvervangend Gezaghebber alles gedaan was, wat onder de omstandigheden dienstig bleek en dat het hun onbekend was, dat er onder de bevolking gevoelens van ontevredenheid over de handelingen van het plaatselijk bestuur heerschten. Deze verklaring strookt ook 
met het feit, dat gedurende een verblijf van zeven dagen van den Gezaghebber Lampe op St. Eustatius geen gebruik werd gemaakt van de door dezen ambtenaar opengestelde gelegenheid aan het publiek om hun grieven, van welken aard ook, aan hem kenbaar te maken. Bij een door den waarnemenden Gouverneur bij zijn bezoek aan St. Eustatius naar aanleiding van een herhaald desbetreffend verzoek van de Heeren Van Putten en Lespier ingesteld persoonlijk onderzoek, bleken de tegen den Heer Kruythoff geuite klachten eveneens meerendeels ongegrond te zijn. Van deze gelegenheid maak ik gebruik aan Uwen Raad tevens aan te bieden een afschrift van de notulen van de vergadering van 8 Januari dj. van den Raad van Politie op meergenoemd eiland, welke vergadering op verzoek van de Landraden werd belegd, speciaal om, zooals het lid Horton opmerkte, in 's Bestuurs oogen eenigszins weer goed te maken de handeling van enkelen onder het Statiaansche volk, die tijdens het vorenvermeld bezoek van den waarnemenden Gouverneur op St. Eustatius, de campagne gevoerd hebben tegen den persoon van den plaatsvervangenden Gezaghebber, den Heer Kruythoff. Ten slotte kan ik Uwen Raad mededeelen, dat ik de vervanging van den Heer Kruythoff als plaatsvervangend Gezaghebber op St. Eustatius overweeg, omdat ik de positie als hoofd der school en vervangend Gezaghebber in een en denzelfden persoon vereenigd niet gewenscht acht."

De Voorzitter leest de bij evengemelde gouvernementsdepêche overgelegde afschriften van notulen van de vergaderingen van den Raad van Politie op St. Eustatius van 7 October 1928 en 8 Januari 1929 voor, welke aldus luiden:

Anno 1928 no. 4.

Meeting of the Court of Policy held in St. Eustatius on Sunday the seventh of October 1900 and twenty-eight.

Present: His Honour Mr. W. Lampe, acting Gezaghebber of the Dutch Windward Islands.

His Honour Mr. S. J. KruYthoff, Local-Gezaghebber. $\left.\begin{array}{ll}\text { Mr. A. K. VALK } \\ \text { Messieurs } \\ \text { Mr. J. W. HoRTon }\end{array}\right\}$ Local Counsellors, Mr. C. G. Buncamper, Secretary.

The President opens the meeting, requests the Secretary to read the minutes of the last meeting, which is done, approved of and signed and further apologizes for having convened a meeting on this day, a Sunday, but attributes his action to urgency of circumstances owing to his one-daystay in this Island. He informs the Court that the purpose of the present meeting is, firstly to express his deep-felt sympathy with the people of the Island who have suffered by the disastrous hurricane of 12/13 Sept. and secondly to assure the Court of his alertness to leave nothing undone in order to obtain the necessary alleviation for the sufferers of the experienced catastrophe. That he is fully confident that His Excellency the acting Governor of Curaçao will give all help and support needed under the pressing needs of the community as great interest has been shown by $\mathrm{H}$. Ex. since the hurricane in his afflicted dominion, and that help has not only been obtained from, but also insured by the Chief Executive. Upon this the Pres- 
ident lays over a telegram received by him via $\mathrm{H}$. E. from His Excellency the Minister of Colonies containing H. M. the Queen's expression of sympathy with the hurricane-stricken inhabitants of this Island. $\mathrm{He}$ also makes known that in behalf of the people he has already returned thanks to $\mathrm{H}$. M. through the same channel.

Hereafter the Court unaminously adopts the following motion in token of appreciation of the timely help rendered by H. Exc. the acting Governor.

„The Court of Policy in the Island of St. Eustatius being sensitive for „the prompt and much needed help rendered by His Excellency the Act„ing Governor of Curaçao to the stormstricken inhabitants of this Island "on the occasion of the hurricane which swept over the Lesser Antilles „on the 12th to 13th Sept. 1928, by means hereof beg to offer to His Ex"cellency the acting Governor of Curaçao, Mr. M. van Dijk, a vote of "thanks for the timely assistance rendered to the poor inhabitants „at their hour of need and to express to His Excellency the assurance of their „deepest appreciation".

In discussing further the interests of the shelterless the Court decides to have the destroyed cottages replaced by new dwellings of two dimensions nl. $10 \times 20$ for large and $9 \times 14 \mathrm{ft}$. for small family. The President commissions the Local Gezaghebber to ascertain how many houses of such sizes will be required.

As far as maintaining a regular and permanent mailservice is concerned the President informs the Court that he has already taken steps and asked H. E. the Governor to purchase a mailschooner in the place of the Virginia.

Before adjourning the present meeting, the President wishes to know from the people's Representatives if the rumors at present in circulation of prevailing dissatisfaction with the Local administration during and after the hurricane are true and if so to state to him the grievances of the people, to which both Members reply that to their knowledge all has been done by the Local Gezaghebber that could be expected under the circumstances and that no one had been to them with any complaint, and that they are not aware of there having existed any feeling of dissatisfaction among the people.

The Local Gezaghebber, Mr. Kruythoff, being present to the meeting is called upon by the President to utter his sentiment in regard to the rumors in circulation, who states, that his efforts in endeavouring to get people to help at the time of need has been misinterpreted by a few faultfinders as „rashness"; that soft means and kind words can not suppress a mob and are of no avail when one wants to get the masses moving and doing; that some of the working people actually refused to render any assistance whatsoever unless they knew ",how much they would get”; that he was actually grieved to see how little co-operation there existed among certain classes at such trying times.

There being nothing else to discuss the President, after putting the question around declared the meeting closed.

For true copy, The Secretary,

(get.) Buncamper.

Anno 1929. no. 1.

Minutes of the meeting of the Court of Policy at St. Eustatius, held on Tuesday, January 8th, 1929. 
Present: Mr. W. Lampe, Acting Gezaghebber of the Dutch Windward Islands, President.

\author{
A. K. VALK \\ Messieurs J. W. HoRTon, Local Councillors. \\ C. G. Buncamper, Secretary.
}

The President opens the meeting, requests the Secretary to read the minutes of the last meeting, which is done, approved of and signed.

He then declared that this meeting is convened at the special request of the Local Councillors, and subsequently grants the word to the junior member, Horton, who seizes said opportunity to declare the following:

„We have requested a meeting as already stated to discuss various im„portant matters; 1st. we desire to impress upon the Government the ter„rible fact that the island is fast becoming depopulated there being a gene„ral exodus to Curaçao; this caused by the lack of employment; people „do not leave the island as a matter of choice, they are driven away by „force of circumstances as at the present time there is no employment for „them. Weare all aware of the fact that there is no capital in the island and „unless capital is introduced and invested on some industry, thereby giv„ing employment to the masses the outlook is deplorable. Lately the Gov„ernment has given food to the hungry, for which we are not unmindful „or ungrateful but this cannot continue neither can it be expected. „Man "must earn what he gets". Therefore the only manner in which the island „can be helped is by the introduction of some kind of industry.

"The all-important question therefore rises, what will happen if nothing is done to give [work ?] to the inhabitants?

„Again we desire specially to thank His Excellency, the Acting Govern"or for his visit to our island, for the help given to the sufferers from the „hurricane and for this strenuous efforts in raising funds to build and re„paire houses for those, whose homes have been damaged or demolished. „We regret that during His Excellency's visit the attitude of a few of in„habitants, acting under evil influence and prompted by ill-will towards „the Local Chief of this place, made His Excellency's visit somewhat un"pleasant and we take this opportunity to assure His Excellency that such „an attitude is not countenanced or appreciated by the general public and "we again tender to His Excellency our tribute of thanks for the good he "has already done and for all that will be accomplished in the future "through His Excellency's good office."

The senior member, Valk, on being granted the word, seconds member Horton's sentiment in every respect and makes known that he has further nothing more to say.

Member Horton resumes the word and thanks the President for the interest he has taken in the Island-under the present condition.

The President takes the word and declares that he fully realizes that Statia is at present in a bad state, economically and the Island has his special attention and he promises to do all that lies in his power to promote a better condition for the future and ultimately thanks both members for the favourable comment on his administration.

There being nothing else to discuss the President after putting the word around, declares the meeting closed.

St. Eustatius, January 10th, 1929.

for true copy,

Voor Afschrift.

(get.) BunCAMPER.

De Gouvernements-Secretaris,

(get.) BoomgaArt. 
Op voorstel van den Voorzitter wordt besloten den Gouverneur dank te betuigen voor de bij gemelde gouvernementsdepêches gedane mededeelingen.

Eindelijk nog een ingezonden stuk, eveneens naar aanleiding van het ingezonden stuk van ,Tiller of the Soil” in de Amigoe di Curaçao van 4 Mei 1929, in hetzelfde blad van 15 Juni 1929, bijblad, no. 2371, luidende:

St. Eustatius, May 30th 1929.

The Editor of the „Amigoe di Curaçao”.

Dear Sir,

It is not only with a feeling of surprise but chiefly of disappointment that we have read the contemptuous article taken up in your issue of the fourth of May 1929, and signed by one „Tiiler oi the Soil", and wherein the writer disapproves of the manner in which the hurricane-relief funds have been and are being handled by the Gezaghebber of the Dutch Windward Islands and his representative at St. Eustatius.

The article in its entirety so devoid of truth, and obviously written with no other purpose but that of evil, has been read with a smile of doubt by those who know better and are acquainted with the fact, that only personal animosity could have been the chief factor in prompting the writer to produce such a masterpiece of falsehood. In fact, we need not enter into confutation of the statements made by the writer, for it would take too much time and space, and why attempt at adjustment where a subject has already been gallantly defended and clearly explained in an interfeuillet in the issue of the 11 th of same paper!

We do not wish to enter into polemics, nevertheless, we cannot conscientiously allow such an article go by - perhaps working its harm without giving to the reading Public the benefit of knowing the exact truth of the whole matter.

What we are publishing here today is not gossip gleaned from the mouth of the man in the street, but is firsthand furnished information.

We happen to know, and it may serve as a consolation to the T. of the S. and his disciples, that it is the intention of the Gezaghebber of the Dutch W. Is. to duly render complete and lucid account of all relief work carried on in the Dutch W. Is, and to have same published, thereby giving a chance to the Public to judge for themselves how and in what way the funds have been used. Had T. of the S. but waited with his criticism until then, he would undoubtedly have been less rash in his judgment and more reasonable in his demands. We dare say however that this masterpiece has been rather premature.

In the first place we must mention that it could not reasonably be expected of the Gezaghebber to start hurricane-relief operation before being in possession of the funds as $\mathrm{T}$. of the $\mathrm{S}$. seemingly wanted him to do. It must not be forgotten that said sum had to be collected abroad, and remitted to him, which latter only took place about the middle of Jan. Then, plans for the reconstruction-programme had to be made, discussed, and adjusted in ratio to the available funds and when we consider the time ab- 
sorbed in the ordering of material from distant countries and the various difficulties and drawbacks thereby experienced, we may with propriety declare that the hurricane-relief-work has made rapid progress instead.

We are at present at the end of May, and have the pleasure already of presenting our readers with the following brief done at St. Eustatius.

Of the number of 40 totally destroyed huts, stand, already completed and occupied, 13 neatly built and prettily painted little wooden cottages of various sizes, accomodating larger or smaller families, while an additional 4 are under completion. It is expected that before the end of June about 25 cottages - the number required - shall have been completed. For the remainder of abovementioned number, monetary compensation has been given, as the owners had either been absent from the island or preferred to receive the cash.

Reconstructive work has been done to 25 houses that suffered partial damage, while 20 overturned houses have been righted and 2400 feet of lumber, and zinc and other material have been distributed to more than 50 persons to enable them to remedy the slight damages sustained. A provisional monetary remuneration of $25 \%$ of the official value of propertydamage has already been handed to 70 individuals exclusive of the above, while $20 \%$ has been turned over the 150 stockkeepers for losses in stock and poultry, to say nothing of help in natura that has been given to 79 planters in the form of selected seed yam, of which there was a great scarcity in the island at the time. Thus in all some 300 individuals have already received compensation.

It may be well to mention that the figures of losses taken as a basis were those submitted by the storm committee, comprising amongst others, Messrs. J. S. van Putten and J. G. Lespier, who shortly after completion of some hurricane data, tendered their resignation on account of their indisposition to work of material nature as well as personal animosity against the Local Chief.

The amount of $f 5000$ allowed by the Government for immediate reliefwork, was not only destined for St. Eustatius, as T. of the S. has recently broadcasted in his falsetto programme. About half of said sum was allocated to St. Eustatius, and we are sure that had it not been for the work carried on by the means of this amount in : the clearing of debris, righting of overturned houses, burying of dead animals etc. the need and calamity resultant of the storm, would have been much more disasterous. This money was well expended, for, when His Excellency, the Governor visited St./Eustatius in December, the roads etc. were all in post-huricane condition.

With regard to the distribution of foodstuff we shall only mention, rhat the remarks made by $\mathrm{T}$. of the $\mathrm{S}$. are so unwarrantable and absurd as to be beneath notice. For, who in St. Eustatius is not aware of the well organized distribution of foodstuff in spite of the lack of cooperation of those who proclaim and pretend to have the interest of the people at heart!

For, had it not been for the personal interest of the Local Gezaghebber assisted by the Lady Receiver, the Post Office Clerk and an agent of police, the foodstuffs would probably still be stored in the warehouse on the Bay. A well thought out ticket system had been responsible for the succesful and peaceful flow of events. About 300 names of needy ones had been submitted by the Clergymen of the island's two predominating denomi- 
nations, to the bearers of these names rations had been dealt out weekly.

Much more can be said to eradicate the many false statements made by the $\mathrm{T}$. of the $\mathrm{S}$. but we deem it beneath our dignity to go further into the matter. We only want to remain objective and to prove to the reading Public that good work has been and is still being accomplished by the Gezaghebber of the Dutch W. Is. and his representative at St. Eustatius, with the funds entrusted to them. Instead of it being a regrettable deed, as $\mathrm{T}$. of the S. bewails, that said fund had been placed unconditionally in the hand of said Gezaghebber, it must be considered a great boon to the people of St. Eustatius that such had been the decision at Curaçao.

The St. Eustatius has not only received the „Lion's Share” of the money, but what is of as much importance, has particularly got the worth of every cent allocated to him and without his assistance. The impartiality and promptitude which characterize this hurricane-relief-work can only be appreciated by the many grateful ones who think otherwise than T. of the $\mathrm{S}$.

Finally we beg to state that the relief work is not yet finished, is going ahead at full speed, and, if we understand aright, there is a surprise yet in store for the T. of the S.

Thanking you Mr. Editor for the space allowed me

$$
\text { Very respectfully yours, }
$$

A St. Eustatian."

Tenslotte moge ik zelf nog mededeelen uit goede en betrouwbare bron vernomen te hebben, dat in Juli 1929 alle noodige orkaanwoningen, allen geverfd en wel, gereed gekomen zijn en blijkbaar een zoo gunstigen indruk op de bevolking gemaakt hebben, dat vele huiseigenaars het goede voorbeeld gevolgd hebben en hunne woningen eveneens hebben laten verven. Door een economisch beheer van het orkaanfonds zal de Gezaghebber vermoedelijk in staat zijn, na de verevening van alle rekeningen, toch nog voldoende over te houden om nog eene uitkeering te doen aan een 50 -tal personen, die geringe schade hebben geleden, maar die nog geen geldelijke compensatie daarvoor gekregen hebben.

Met het vorenstaande hoop ik een en ander ook van een andere zijde belicht te hebben.

Willemstad, Curaçao, 1 October 1929 